Вінтоняк Наталія Амитрівна, молодший науковий співробітник Науково-дослідного інституту приватного права і піАприємництва імені академіка Ф.Г. Бурчака Національної академії правових наук України

\title{
НАБУТТЯ КОРПОРАТИВНИХ ПРАВ ОДНИМ ІЗ ПОДРУЖЖЯ
}

Постановка проблеми. Усе більше осіб, які перебувають у шлюбі, стають учасниками корпоративних відносин за рахунок переАання як вклаАу Ао статутного капіталу юридичної особи корпоративного типу майна, що належить подружжю на праві спільної сумісної власності. Питання набуття корпоративних прав набуває актуальності у зв'язку з тим, що в судовій практиці поширені спори за позовом того з подружжя, без згоди якого таке майно передане як вклаА Ао статутного капіталу юридичної особи корпоративного типу.

Стан АосліАження проблеми. Сьогодні не існує системних розроблень, присвячених досліАженню набуття корпоративних прав одним із подружжя. Окремі питання корпоративних прав подружжя досліАжувалися у працях Т.В. Боднар, В.А. Васильєвої, І.В. Жилінкової, В.М. Кравчук, І.В. Спасибо-Фатєєвої та інших.

Метою статті $€$ досліАження набуття корпоративних прав оАним із подружжя. Наукового аналізу потребує також питання згоди оАного з подружжя піА час набуття корпоративних прав за рахунок майна, що належить подружжю на праві спільної сумісної власності.

ВикиаА основного матеріалу. У науковій літературі поширеним $€$ поділ піАстав набуття корпоративних прав, як і права власності у цілому, на первинні та похідні. В.М. Кравчук зазначає, що первісними піАставами виникнення цього права $€$ набуття акцій (часток) піА час створення товариства, піА час збільшення статутного капіталу або придбання акцій (часток), які належали товариству. ПохіАними піАставами виникнення права на частку (акції) є договір, спадкування та правонаступництво піА час припинення юридичної особи [1, с. 12].
В.А. Васипьєва зазначає, що суб'єктивне корпоративне право - це, насампереА, право засновника, тобто особи, яка прийняла рішення про створення (заснування) корпоративної юриАичної особи [2, с. 157]. У першу чергу піАставою набуття корпоративних прав є створення юриАичної особи корпоративного типу, пов'язане зі зАійсненням їі державної реєстрації у встановленому законом поряаку, оскільки із цього моменту учасники набувають корпоративних прав віАповіАно Ао заійснених внесків Ао статутного капіталу, а між учасником і такою юридичною особою встановлюється корпоративне правовіАношення.

Не вАаючись Ао Аетального аналізу піАстав виникнення корпоративних прав, розглянемо внесення майна до статутного капіталу юридичної особи корпоративного типу, що належить подружжю на праві спільної сумісної власності, як вкладу до статутного капіталу юридичної особи корпоративного типу - як первісний спосіб набуття корпоративних прав, та укладення цивільно-правових Аоговорів - як похіАний. У контексті розгляАУ цих піАстав особливого значення набуває ЗгоАа оАного з подружЖя.

ЗгіАно зі ст. 65 СК України Аружина, чоловік розпоряАжаються майном, що є об'єктом права спільної сумісної власності подружжя, за взаємНОю ЗгоАОЮ.

Оскільки частки кожного з подружжя у спільній сумісній власності $\epsilon$ невизначеними, вони мають координувати свої Аії щодо цього майна. У зв'язку із цим невизначеність часток у праві власності подружжя на майно спричинює Ава важливих наслідки:

1) по-перше, за загальним правилом, Аії одного з поАружЖя щоАо волоАіння та розпоряАЖення спільним майном розглядаються як Аії подружжя. 
Згода іншого з подружжя переАбачається до того часу, поки не буде доведено протилежне;

2) по-Аруге, у випалках, передбачених законом, Аля зАійснення певних юриАичних Аій потрібна воля подружжя. Це пояснюється тим, що річ належить подружжю на праві власності без визначення часток, тому розпоряАження зАійснюється в обсязі речі у цілому, а не її окремої частки [3, с. 60].

Вважається, що Аля розпоряАження майном необхінна згода обох із подружжя. Така згода в одних випадках презюмується, а в інших - має бути висловлена в певній передбаченій законом формі [4, с. 65].

У випадку набуття корпоративних прав одним із подружжя на підставі внесення до статутного капіталу юридичної особи корпоративного типу як вкладу об'єктів права спільної сумісної власності піА час створення юриАичної особи жодних правочинів не вчиняється. ВідповіАно, буде вважатися, що об'єкти права спільної сумісної власності передані до статутного капіталу за взаємною згоАою подружжя. У Ааному випаАку вважатиметься, що той із подружжя, хто став учасником юриАичної особи корпоративного типу, передав об'єкти права спільної сумісної власності за згодою іншого з подружжя. Тобто Аіє презумпція згоди подружжя, яка поширюється на володіння, користування та розпорядження майном у цілому. Вважається, що будь-які Аії оАного з подружжя щодо розпоряАження об'єктами права спільної сумісної власності з моменту реєстрації шлюбу будуть вважатися такими, що вчинені за згодою Аругого з подружжя, в тому числі і передання спільного сумісного майна Ао статутного капіталу юридичної особи корпоративного типу.

Верховний СуА України в Постанові віА 19 ^ютого 2014 року у справі № 6-5цс14 за позовом про визнання правочину недійсним та скасування державної реєстрації змін Ао статуту піАприємства зазначив: "Відповідно до ч. 1 ст. 65 СК України Аружина, чоловік розпоряджаються майном, що є об'єктом права спільної сумісної власності подружжя, за взаємною згодою.

ОАним із виАів розпоряАження власністю $€$ право власника використовувати своє майно Аля зАійснення господарської діяльності" [5].

Якщо ж звернутися до набуття корпоративних прав оАним із подружжя на підставі цивільно-правових Аоговорів, то тут ситуація дещо склаАніша, оскільки виникає питання, чи потрібна письмова згода подружжя піА час укладення одним із подружжя, Ао приклаАу, Аоговору купівлі-продажу корпоративних прав, якщо останній виступає покупцем. ААже цікком імовірно, що набуття корпоративних прав за договором зАійснюється за рахунок майна, що належить подружжю на праві спільної сумісної власності.

У відповідності Ао ст. 328 ЦК України право власності набувається на підставах, що не заборонені законом, зокрема із правочинів. Право власності вважається набутим правомірно, якщо інше прямо не випливає із закону або незаконність набуття права власності не встановлена судом.

У відповіАності Ао ст. 65 СК України піА час укладення Аоговорів одним із подружжя вважається, що він Аіє за згодою Аругого з подружжя. Аружина, чоловік має право на звернення до суду з позовом про визнання Аоговору неАійсним як такого, що укладений Аругим із подружжя без іï, його згоАи, якщо цей Аоговір вихоАить за межі Арібного побутового.

ПіА час укладення Аоговорів одним із подружжя вважається, що він Аіє за згодою Аругого з подружжя. У цій нормі - не лише презумпція згоди Аругого з подружжя, а й своєріАне законне преАставництво чоловіком, Аружиною Аругого з подружжя як співвласника [6, с. 463]. Згода як правомірна Аія визначається як одностороннє волевиявлення суб'єкта сімейних правовіАносин, що свідчить про схвалення вчинення іншим суб'єктом сімейних правовіАносин юридично значимих Аій і настання віАповіАних насліАків [7, с. 11]. Можна сказати, що згода є Аією одного з подружжя на схвалення будь-яких Аій іншим із подружжя.

3 аналізу норм ст. 65 СK України випливає, що законодавець виділив виАи правочинів, щодо яких повинна бути наАана згода оАного з подружжя: правочин, який виходить за межі Арібного побутового; правочини стосовно цінного майна; правочини, що потребують нотаріального посвіАчення і (або) державної реєстрації.

Що стосується Аоговорів, пов'язаних із набуттям оАним із поАружжя корпоративних прав, то вони оАнозначно виходять за межі Арібного побутового правочину. Із цього випливає, що Аружина та чоловік можуть звернутися Ао суду про визнання такого Аоговору неАійсним у силу ст. 65 СК України. Крім того, такі договори можуть укладатися і з приводу цінного майна. ВіАповіАно, вклаА Ао статутного капіталу юридичної особи корпоративного типу може формуватися за рахунок майна, що належить подружжю на праві спільної сумісної власності, і крім того, є Аля подружжя чи оАного з них цінним. 


\section{4 回回回回回回回回回回回回回回回回回回回回 Випуск 33}

3 урахуванням ст. 208 ЦК України, що визначає, які правочини належить вчиняти в письмовій формі, можна зробити висновок, що Аоговір, пов'язаний із набуттям корпоративних прав, повинен бути вчинений у письмовій формі. Крім того, щонайменше, з аналізу ст. 65 СК України випливає, що піА час укладення правочинів, пов'язаних із набуттям оАним із подружжя корпоративних прав, повинна надаватися згода одного з подружжя. I така згода в першу чергу повинна бути письмовою. ВіАсутність такої згоди буде беззаперечною піАставою Аля звернення Ао суду про визнання Аоговору неАійсним.

ВіАповіАно Ао ч. 2 ст. 65 СК України Аружина, чоловік має право на звернення Ао суду з позовом про визнання договору недійсним як такого, що укладений Аругим із подружжя без їі, його згоди, якщо цей Аоговір вихоАить за межі Арібного побутового. Т.В. Боднар вважає, що таким чином, віАповіАно Ао ч. 2 ст. 65 СК України віАсутність ЗгоАи іншого З поАруЖЖя СліА Вважати ЄАиною ПіАставою визнання неАійсним АоГовору щоАО розпорядження майном, що є об'єктом права спільної сумісної власності, уклаАеного одним із подружжя [8, с. 81].

На практиці договори, пов'язані 3 набуттям (віАчуженням) корпоративних прав, укладаються без згоди іншого з подружжя, хоча вони виходять за межі дрібних побутових правочинів. Це пов'язано з тим, що спеціальне законодавство не вимагає згоди іншого з подружжя на укладення таких Аоговорів. ОАнак законодавство надає можливість іншому з подружжя звернутися з позовом Ао суду про визнання Аоговору неАійсним. ПіА час поділу спільної сумісної власності такі позови $€$ особливо поширеними.

ЗгіАно із ч. 1 ст. 215 ЦК України піАставою недійсності правочину є недодержання в момент вчиненняправочинустороною (сторонами) вимог, які встановлені частинами першою, третьою, п'ятою та шостою статті 203 цього Кодексу. ВілповіАно Ао ч. 1 ст. 203 ЦК України зміст правочину не може суперечити цьому Кодексу, іншим актам цивільного законодавства, а також інтересам Аержави і суспільства, його моральним засадам.

Згідно із ч. 2, 3 ст. 215 ЦК України неАійсним $€$ правочин, якщо його неАійсність встановлена законом (нікчемний правочин). У цьому разі визнання такого правочину неАійсним судом не вимагається. У випадках, встановлених цим Кодексом, нікчемний правочин може бути визнаний судом Аійсним. Якщо неАійсність правочину прямо не встановлена законом, але одна із сто- рін або інша заінтересована особа заперечує його Аійсність на підставах, встановлених законом, такий правочин може бути визнаний судом неАійсним (оспорюваний правочин).

ЗгіАно із ч. 4 ст. 369 ЦК України правочин щодо розпоряАження спільним майном, вчинений оАним із співвласників, може бути визнаний судом недійсним за позовом іншого співвласника в разі віАсутності у співвласника, який вчинив правочин, необхіАних повноважень.

Абз. 4 ч. 26 Постанови Пленуму Верховного Суду України «Про судову практику розгляАу цивільних справ про визнання правочинів неАійсними" № 9 віА 06 мистопада 2009 року [9] містить таке положення: якщо преАметом правочину є майно, яке належить особам на праві спільної сумісної власності, інші співвласники віАповіАно АО частини Аругої статті 369 ЦК Ао участі у справі не залучаються, оскільки правочин щодо розпоряАження спільним майном вважається вчиненим за згодою всіх співвласників. За відсутності такої згоди інші співвласники віАповіАно АО частини четвертої статті 369 ЦК можуть преА'явити позов про визнання такого правочину неАійсним.

Статтею 216 ЦК України визначено, що неАійсний правочин не створює юридичних насліАків, крім тих, що пов'язані з його неАійсністю.

У разі неАійсності правочину кожна із сторін зобов'язана повернути Аругій стороні в натурі все, що вона одержала на виконання цього правочину, а в разі неможливості такого повернення, зокрема тоді, коли одержане полягає в користуванні майном, виконаній роботі, наданій послузі, - віАшкоАувати вартість того, що одержано, за цінами, які існують на момент віАшкоАування.

Вищенаведене ще раз піАтверАжує необхіАність отримання згоди піА час укладення цивільно-правових Аоговорів, пов'язаних із набуттям корпоративних прав оАним з поАружжя. Крім того, останнім часом суди ухвалюють рішення, згіАно з якими віАсутність письмової згоАи сама по собі не може бути піАставою Аля визнання Аоговору, укладеним оАним із поАружжя без згоди Аругого, неАійсним [10, с. 121]. Така ситуація ставить того з подружжя, який не $є$ стороною Аоговору, у ще більш невигідне становище.

ЗгіАно із ч. 3 ст. 65 СК України Аля укладення оАним із поАружжя Аоговорів, які потребують нотаріального посвіАчення і (або) Аержавної реєстрації, а також договорів стосовно цінного майна, згода Аругого з подружжя має бути подана письмово. Згода на укладення Аоговору, який потребує нотаріального посвідчення і (або) дер- 
жавної реєстрації, має бути нотаріально засвіАчена. Законодавець не встановлює норми щодо обов'язкового нотаріального посвідчення Аоговорів на відчуження корпоративних прав, крім випадків, передбачених статутом чи за Аомовменістю сторін Аоговору. На нашу Аумку, Аоговір на відчуження корпоративних прав обов'язково повинен бути нотаріа^ьно посвіАченим, що детальніше буде розглянуто в пілрозділі 3.1. цієї роботи.

у випадку нотаріального посвіАчення Аоговору на віАчуження корпоративних прав той із подружжя, який виступатиме набувачем за договором за рахунок майна, що належить подружжю на праві спільної сумісної власності, повинен отримати нотаріально засвідчену заяву про надання згоди віА іншого з подружжя.

У відповіАності до п. 4.2. Глави 1 РозАілу ІІ Наказу Міністерства юстиції України № 296/5 віА 22.02.2012 року "Про затвердження поряАку вчинення нотаріальних Аій нотаріусами України" піА час посвіАчення правочинів щодо розпоряАження спільним майном подружжя, якщо Аокумент, що посвідчує право власності, оформлений на ім'я одного з подружжя, нотаріус вимагає письмову згоду іншого з подружжя. Справжність піАпису Аругого з подружжя на заяві про таку згоду має бути нотаріально засвідчена [11].

ЗгіАно з МетоАичними рекоменАаціями щоАо посвідчення Аоговорів купівлі-продажу частки в статутному капіталі товариства з обмеженою віАповіАальністю нотаріус піА час посвіАчення Аоговору купівлі-продажу частки у статутному капіталі товариства з метою визначення правового статуту майна перевіряє наявність згоди другого в разі набуття частки за кошти, що є спільною сумісною власністю подружжя. У разі якщо частка у статутному капіталі товариства придбавається одним із подружжя, то нотаріусом вимагається згода Аругого з подружжя на придбання за рахунок спільних грошових коштів [12, с. 4-10].

Така заява з вираженням згоди є простим юридичним фактом, у результаті якого не створюються нові права та обов'язки Аля жодного суб'єкта. У цьому випадку спільне сумісне майно розглядається як неподільна річ, і співвласник надає згоду на відчуження частини у праві власності на цілу річ [13, с. 163].

ПіА час укладення Аоговорів така згода буде обов'язковою і свідчитиме про те, що інший із подружжя був ознайомлений з умовами договору та погодив передання за Аоговором майна, що належить їм на праві спільної сумісної власності. Отримання такої згоди зменшить визнання таких
Аоговорів неАійсними у судовому поряАКу, аАже Ауже часто оАин із подружжя просить визнати такий Аоговір недійсним на тій підставі, що не володів інформацією щодо укладення такого Аоговору або ж взагалі був проти. Крім того, наявність згоАи буде означати, що той із подружжя, який не є набувачем, за договором ознайомлений із правовими наслідками укладення такого Аоговору. А саме з тим, що корпоративних прав за договором він не набуває, оскільки такі права $\epsilon$ суб'єктивними правами учасників корпоративних відносин, а набуває право вимоги, яке може бути реалізоване піА час поділу спільної сумісної власності подружжя. І жодної згоди на подальше зАійсненні корпоративних прав тим із подружжя, який є учасником, не буде вимагатися.

Питання згоди подружжя щодо вчинення правочинів, пов'язаних із набуттям корпоративних прав, заслуговує особливої уваги. Абсолютна визначеність цього питання Аопоможе уникнути порушень і зловживань правом Аругого з подружжя. Інший із подружжя виступає Аещо слабшою стороною у віАносинах, які складаються в такому випадку, а тому потребує захисту. Надання нотаріально засвідченої заяви про надання згоди на укладення таких Аоговорів іншим із подружжя буде піАтвердженням того, що Аоговір укладається за згоди іншого з подружжя, в інтересах Авох із подружжя, та обидва з подружжя володіють інформацією щодо передання майна, що належить їм на праві спільної сумісної власності, Ао статутного капіталу юридичної особи корпоративного типу.

Висновки. У випалку внесення Ао статутного капіталу юридичної особи корпоративного типу майна одним із подружжя як вкладу піА час створення юриАичної особи корпоративного типу вважається, що об'єкти права спільної сумісної в^асності передані до статутного капіталу за взаємною згодою подружжя. Тобто Аіє презумпція ЗгоАи поАружжя. БуАь-які Аії оАного з поАружжя щодо розпоряАження об'єктами права спільної сумісної власності з моменту реєстрації шлюбу вважаються такими, що вчинені за згодою іншого з подружжя, зокрема і внесення об'єктів права спільної сумісної власності як вкладу Ао статутного капіталу юридичної особи корпоративного типу.

Отримання нотаріально засвідченої заяви про надання згоди іншого з подружжя на укладення Аоговорів, пов'язаних із набуттям корпоративних прав, є підтвердженням того, що договір укладається за згодою подружжя, та обиАва з них волоАіють інформацією щодо передання майна, яке 
належить їм на праві спільної сумісної власності, Ао статутного капіталу юридичної особи корпоративного типу. Отримання нотаріально засвідче- ної заяви про надання згоди іншого з подружжя $€$ гарантією зменшення випадків визнання у судовому поряАКу таких Аоговорів неАійсними.

\section{NITEPATYPA:}

1. Кравчук В.М. Припинення корпоративних правовідносин в господарських товариствах : автореф. дисерт. ... докт. юридич. наук : 12.00 .03 ; ЛДУВС. Харків. 2010. 38 с.

2. Луць В.В., Васильєва В.А., Кібенко О.Р., Спасибо-Фатєєва І.В. Корпоративне право України : підручник / за заг. ред. В.В. Луця. Київ : Юрінком Інтер, 2010. 384 с.

3. Оніщенко О.В. Сімейне право : навч. посіб. Київ : Видавництво Національного авіаційного університету «НАУ-друк», 2009. $112 \mathrm{c}$.

4. Х Харитонов Є.О. Сімейне право України : навчальний посібник. Київ : Істина, 2016. 200 с.

5. Постанова Верхового Суду України від 19 лютого 2014 року, судова справа № 6-5цс14. URL : http://reyestr.court.gov.ua/ Review/37520383 (дата звернення : 21.07.2014).

6. Ромовська 3.В. Українське сімейне право : підручник: академічний курс. Правова єдність, 2009. 500 с.

7. Штыков Д.В. Категория «согласие» среди основных понятий в семейном праве Российской Федерации : автореф. диссерт. ... кандид. юрид. наук : 12.00.03 ; Тверский государственный университет. Москва, 2010. 30 с.

8. Боднар Т.В. Відсутність згоди як підстава визнання правочинів недійсними у сімейному праві України. Проблеми цивільного права та проиесу: тези доп. Учасників наук.-практ. конф., присвяч. світлій пам'яті О.А. Пушкіна, 19-20 трав. 2017 р. Харків : ХНУВС, 2017. С. 80-82.

9. Про судову практику розгляду цивільних справ про визнання правочинів недійсними : Постанови Пленуму Верховного Суду України від 06 листопада 2009 року № 9. URL : http://zakon.rada.gov.ua/laws/show/v0009700-09 (дата звернення : 05.05.2016).

10. Вінтоняк Н.Д. Правова природа згоди подружжя при відчуженні корпоративних прав. Розвиток сучасного приватного права в краӥнах Європи: Матеріали VIII Міжнародного циивілістичного форуму (19-20 квітня 2018 р., м. Київ). Київ, 2018. C. $118-123$.

11. Порядок вчинення нотаріальних дій нотаріусами України : Наказ Міністерства юстиції України від 22.02.2012 року № 296/5. URL : http://zakon.rada.gov.ua/laws/show/z0282-12 (дата звернення : 05.05.2016).

12. Крат В.І., Божок М.О. Методичні рекомендації щодо посвідчення договорів купівлі-продажу частки в статутному капіталі товариства з обмеженою відповідальністю. Київ : Нотаріальна палата України, 2017. 10 с.

13. Д'ячкова Н.Я., Турчин Ф.А. Згода одного з подружжя на вчинення правочинів щодо спільного майна. Право $i$ безпека. 2015. № 2(57). С. 160-165.

\section{Вінтоняк Наталія Амитрівна}

\section{НАБУТТЯ КОРПОРАТИВНИХ ПРАВ ОАНИМ ІЗ ПОАРУЖЖЯ}

Статтю присвячено АосліАженню правового регулювання корпоративних прав подружжя, набутих оАним із подружжя за рахунок майна, що належить подружжю на праві спільної сумісної власності. Розглянуто внесення майна, що належить подружжю на праві спільної сумісної власності, як вкладу Ао статутного капіталу юридичної особи корпоративного типу, як первісний спосіб набуття корпоративних прав, та укладення цивільно-правових Аоговорів - як похіАний. ПриАілено увагу згоді подружжя піА час набуття корпоративних прав оАним із подружжя.

Киючові слова: корпоративні права подружжя, набуття корпоративних прав, юридична особа корпоративного типу, вклаА, статутний капітал, право спільної сумісної власності, згода одного з подружжя.

\section{Винтоняк Наталья Амитриевна}

\section{ПРИОБРЕТЕНИЕ КОРПОРАТИВНЫХ ПРАВ ОАНИМ ИЗ СУПРУГОВ}

Статья посвящена исследованию правового регулирования корпоративных прав супругов, приобретенных оАним из супругов за счет имущества, принадлежащего супругам на праве общей совместной собственности. Рассмотрено внесение имущества, принадлежащего супругам на праве общей совместной собственности, в качестве вклада в уставный капитал юридического мица корпоративного типа, как первоначальный способ приобретения корпоративных прав, и заключение гражданско-правовых договоров - как производный. УАелено внимание согласию супругов при приобретении корпоративных прав одним из супругов.

Киючевые слова: корпоративные права супругов, приобретение корпоративных прав, юридическое лицо корпоративного типа, вклаА, уставной капитал, право общей совместной собственности, согласие одного из супругов. 


\section{Vintonya Nataliia}

\section{ACQUISITION OF CORPORATE RIGHTS BY ONE OF THE SPOUSES}

The paper examines the issues of the legal regulation of spouses' corporate rights acquired by one of the spouses by means of marital property. The two ways of acquiring corporate rights have been discussed, namely investing marital property into the authorized share capital of a corporation as a primary way, and entering into civil agreements as a derivative way.

The issues regarding the acquisition of corporate rights by one of the spouses by means of investing marital property into the authorized share capital of a corporation without the other spouse's consent become more relevant in the dispute resolution practice. Consequently, this paper is aimed at finding ways to resolve the mentioned above issue by way of paying close attention to spousal consent. Clear and unambiguous definition of spousal consent will help to avoid the violation and abuse of rights of either spouse.

It has been investigated that in case one of the spouses invests marital property into the authorized share capital of a corporation on the stage of its incorporation as a predetermined contribution, then it is believed that such act implies mutual consent. In other words, it is presumed consent. Since the moment marriage is registered, any acts by either spouse pursuant to the right to dispose of the property (marital property, in this instance) are deemed to be performed by mutual consent, including investing marital property into authorized share capital of a corporation.

It has been justified that a notary certified consent of one of the spouses to the other spouse entering into civil agreements on acquiring corporate rights by means of investing marital property into the authorized share capital of a corporation serves as proof of being fully aware of the transfer of marital property. The discussed above notary certified consent reduces the risk of contracts on marital property transfer being voided by court.

Key words: corporate rights of spouses, acquisition of corporate rights, corporation, predetermined contribution, authorized share capital, share in authorized capital, shared property rights. 